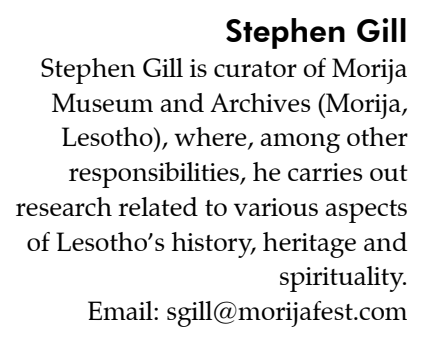

Thomas Mofolo: the man, the writer and his contexts

\title{
Thomas Mofolo: the man, the writer and his contexts
}

A substantial corpus of research has been published on Thomas Mofolo since the 1930s. Earlier portraits of Mofolo as a person leave much room for further amplification and improvement. The present research seeks to greatly enhance our understanding of Thomas Mofolo (1876-1948) by using a wealth of archival material, much of which is located at Moriia Museum and Archives, and interviews with a variety of elderly informants, including Mofolo's last surviving daughter and other family members. As a result, Mofolo can now be seen more clearly as a person within the context of his large extended family, their antecedents in the wider region, his upbringing and educational formation, three successive marriages, professional life and business operations in a number of different contexts, involvement in political life, and the changing nature of his relationship with the church. The current article focuses on Mofolo's antecedents up until he began his literary career in 1905-6 at Moriig, a subject that has received inadequate attention until now. By adding considerable texture to his early life and family history, as well as the historical and religious contexts and currents in which he was raised at Hermon, Qomogomong and Morija, Thomas Mofolo emerges more clearly as an historical figure. For example, as a boy, we learn that Thomas imbibed a great deal from his father Abner Ramofolo Mofolo, a very hard-working and practically-oriented man, who was himself a gifted storyteller. Given the possibility of pursuing higher studies through the Protestant PEMS Mission, Thomas grabbed this opportunity and came to Morija at a particularly fruitul time during the 1890s, a time of ferment and great expectations. Mofolo, as part of an emerging cadre of "progressive ones" (bahlalefi or matsoelopele), developed his linguistic skills and eloquence to the point where, with the support of colleagues, he could dare to attempt something new, a creative synthesis of various forms of storytelling, indigenous and exogenous, in written Sesotho. His literary output has proved to be of enduring significance, and in the process he became, perhaps inadvertently, the father of the African novel. Keywords: Lesotho history; Mofolo family tree; Morija Sesuto Book Depot; Thomas Mofolo biography.

\section{Introduction}

Daniel Kunene, in his analysis of Thomas Mofolo's literary works and his legacy regarding Sesotho literature, compiled what was in 1989 the fullest and most accurate biographical sketch of Mofolo's life. Kunene's research had uncovered new and unexpected information which allowed him to correct certain long-held but erroneous views. As such, he was able to paint a more accurate portrait of Mofolo than hitherto obtained. He wrote:

Perhaps it is fitting that the very last word in this book should be about Thomas Mofolo

himself [...] it has become evident that one cannot separate a man's personal experience 


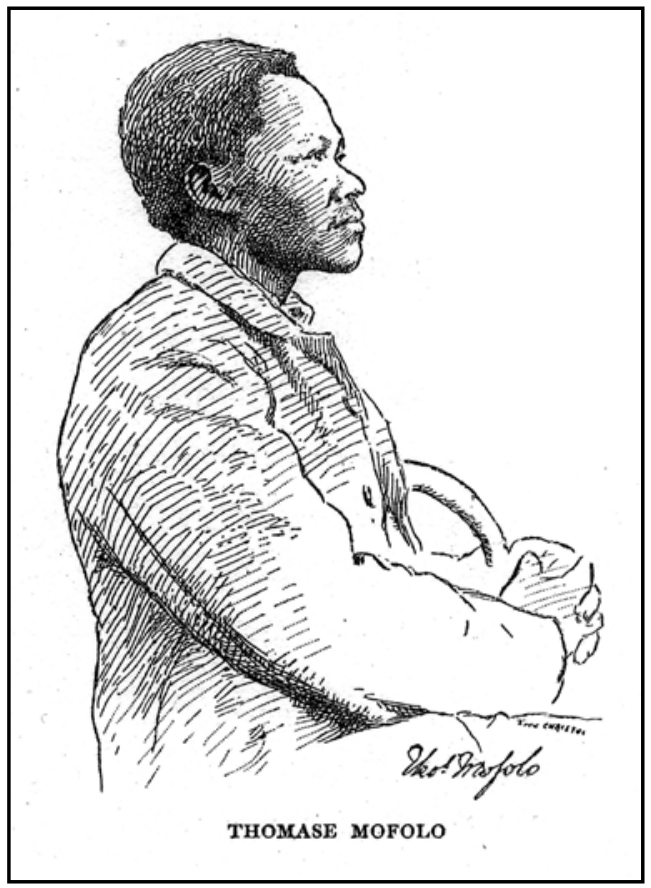

Sketch of Thomas Mofolo by Frédéric Christol (Christol 16).

in life, particularly those of a deeper spiritual significance, from his works. Someone who, as an artist, has made such an impact on the public as Mofolo has, is, so to say, "a man of the people". His love life, his family life, his passions, his successes and failures, his goings and comings-all these not only belong to him individually and privately, but also to all of us collectively and publicly, for he is a man who has touched our souls, he is our idol, and therefore we shall never let him be. (Kunene 241)

Since Kunene's work, little additional research has been carried out to help us understand more fully who Thomas Mofolo was as an historical figure, or to elucidate the various contexts in which Mofolo lived and worked. In the paper which follows, further information in this regard is shared as the first 'fruits' of an on-going research project. Attention here is focused on aspects of Mofolo's life up until 1905-6, that is, just at the point when he began his literary career.

\section{The misty past and the emergence of the Mofolo family in the historical record at Botheta}

The Mofolo "clan" emerges in the historical record in the mid-nineteenth century in what is now the south-eastern Free State, but the record is inadequate. Therefore, for this early period, we may have to use a little more conjecture than is usually desirable.

As part of the larger Bataung ba Molete, the Mofolos and their predecessors had probably been moving over the previous two centuries, like so many other groups of Bataung, a major branch of the Sotho-Tswana, in a general south-easterly direction from the Molopo River down through Bolibeng ba Likubu (the Kroonstad area) into what is now the north-central Free State. These largely self-sufficient agro-pastoralists, like other clans of the Sotho-Tswana which lived by a combination of herding, farming, hunting and gathering, were caught up in the throes of the Lifaqane which swept through the Highveld in the early 1820s. The Mofolos may have sought refuge in the Cape, like so many others, during this period of disruption which unsettled most communities in the region and presented them with intense challenges over the coming decades. Moshoeshoe at Thaba-Bosiu and Sekonyela at Joala-Boholo emerged as the 


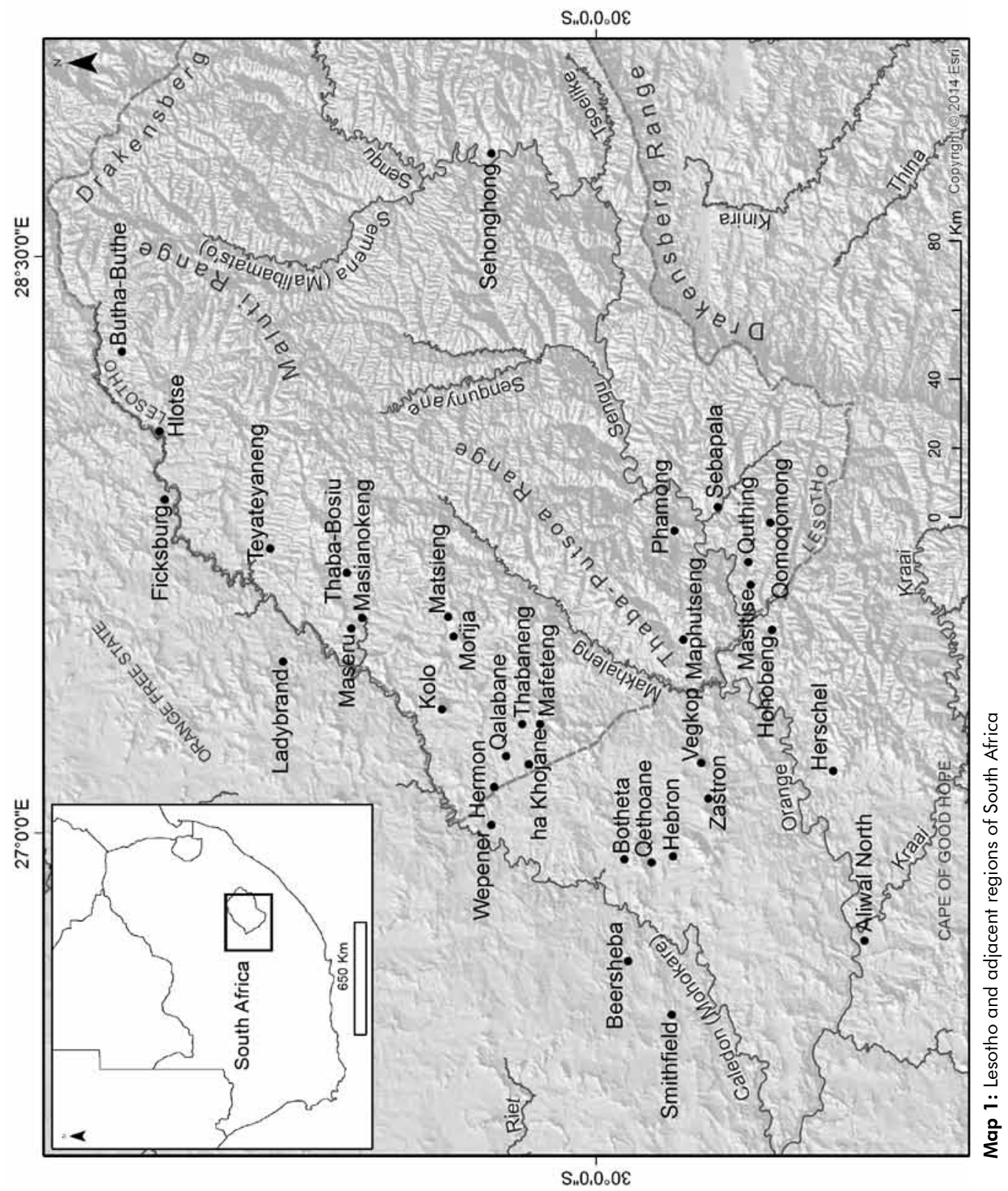


main centres of power in the greater Caledon River valley after 1828, and many of the Bataung ba Molete gravitated towards one or the other, but not all. Some remained in the Cape or other parts of "Trans-Orangia", where they held their own or attached themselves to less well-known leaders. Whatever the case may have been with the Mofolo family, they eventually found a place of relative safety from the late 1840s at Botheta (Kaqhoha), a mountain $25 \mathrm{~km}$ to the northwest of modern-day Zastron.

It is perhaps appropriate at this point to emphasise that the Bataung ba Molete, like most of the Sotho-Tswana and other Bantu peoples, practised an economy of mixed farming; they were able to spread out and gradually settle ever larger areas, intermixing with various peoples (other Sotho, Nguni, San, and so on) and adapting to differing ecological conditions. They had polities of varying sizes which were governed through aristocratic families. Though a balance was often maintained between the interests of the chiefly class (marena) and the commoners (bafo), contestation was also part and parcel of the unfolding drama of these communities.

One element worth noting is that eloquence was highly valued, for in the naming of things, in the rich and expressive language, and in the rituals and customs there resided intelligence and creative power. Oral traditions and genealogies, legends and tales, proverbs, riddles, games, songs, litaola, and other customs and rituals embodied and manifested this intelligence and power; these encapsulated differing paradigms for knowing and processing life experiences, for guiding one through the different stages of life, each stage with its distinctive responsibilities and requirements, inculcating values which were intimately connected to patterns of reciprocal obligation, obligations to the living and to the ancestors.

In remembering the stories and re-telling the dreams, prophecies, history and customs of their families, clans and chieftaincies, different societal formations were able to preserve their sense of identity. They were able to consolidate and adapt, maintaining older traditions while incorporating new elements or off-shoots, moulding and adjusting themselves to changing circumstances, as well as incorporating diverse and novel experiences. This was not a static society but an adaptable and resilient one, able to initiate and take advantage of emerging opportunities.

Eloquence was highly valued because there were no books or papers to help one to remember. So it was in the telling and re-telling of important stories, oral traditions and customs that the most important and formative "information" was passed on from one generation to the next.

The Mofolo descendants of today can trace their history back to a certain point, to a man called Mofolo who lived during the nineteenth century, to this period of nation-building in the sub-continent. Mofolo (hereafter called Mofolo Sr) was the sixth son of Masenkane, the eldest son of Molete, the son of Moleteng oa Tebele. To speak plainly, Mofolo Sr was a very junior son of the senior lineage of the Bataung ba Molete. He was probably born in the early nineteenth century, perhaps in the north-central 
Free State. Scattered with others by the Lifaqane, he and some of his people fled to the south, and eventually ended up residing at Botheta.

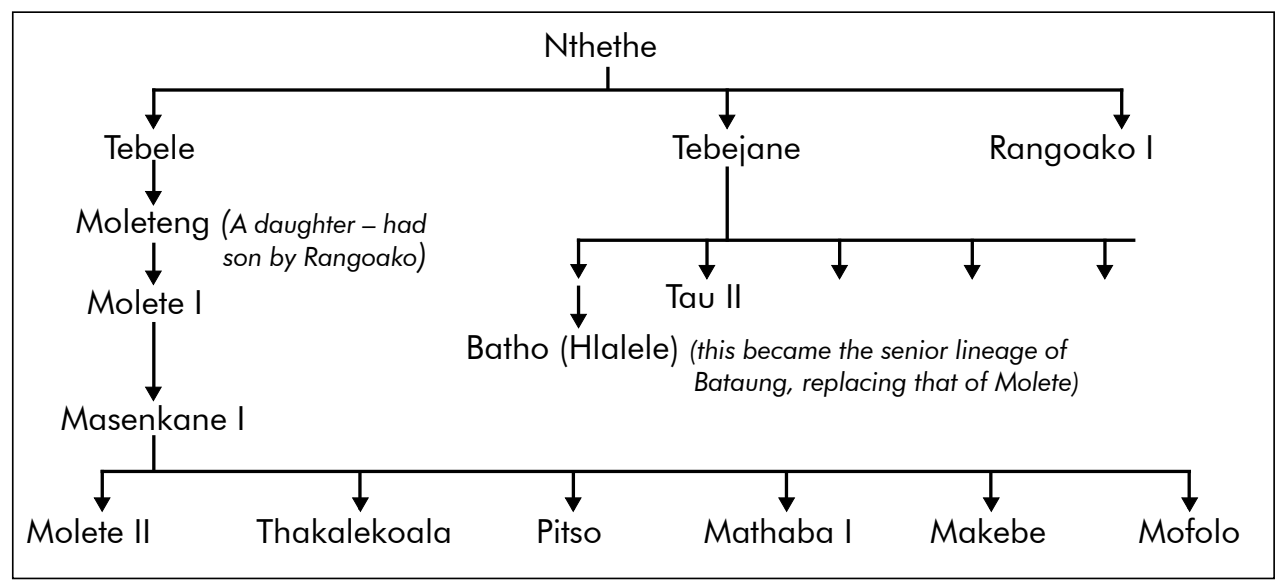

Figure 1: Bataung ba Molete, according to T. M. Sekonyela

Although current members of the Mofolo family have no tradition regarding the family's sojourn at Botheta, such details can be added with the assistance of the archival records of the Paris Evangelical Missionary Society (PEMS) at Morija. It is in these written records that the first solid piece of evidence appears in this regard. Mofolo Sr's son, Abner (Ramofolo) Mofolo, married a young woman, Aleta 'Mapheko, in January 1872 at Hermon Mission. According to the Marriage Register, Abner had been born at Botheta. ${ }^{1}$ He was probably in his early to mid-20s in 1872 , making his year of birth in the late 1840s. Thus, we can place the Mofolo family at Botheta with some certainty from that time, if not a little earlier. It is also recorded that Abner's father, Mofolo, was already deceased in 1872, but his mother Leila was alive.

Mofolo Sr (Abner's father) may not have been a Christian, but his wife Leila certainly became one at a certain point in time, because her death is recorded in 1881 in the records of Hermon, one of many parishes established under the auspices of the Paris Evangelical Missionary Society. When and where Leila became a convert is not known, but it was certainly before 1876 when Rev. Hermann Dieterlen arrived at Hermon.

We are not sure how many wives Mofolo Sr had, but we can say that his eldest son by Leila, called Jemisi (James), may have been born at Botheta. Certainly, Jemisi's younger brother Abner was born there in the late 1840s. It may not be coincidental that Hebron, set up by Rev. Louis Cochet of the PEMS about $15 \mathrm{~km}$ to the south of Botheta, was established in 1847. Cochet tried to minister to the BaMonaheng and other groups in the area, and gradually built up a small congregation of members and a larger group of 'enquirers' or 'listeners' who by the mid-1850s numbered between 100 and 200 in total. Leila and other members of the family may well have become 
exposed to Christian teachings during this period, as well as to Dutch and the practices of the white settlers and people of mixed ancestry, many of whom had become acculturated to the ways of the Dutch.

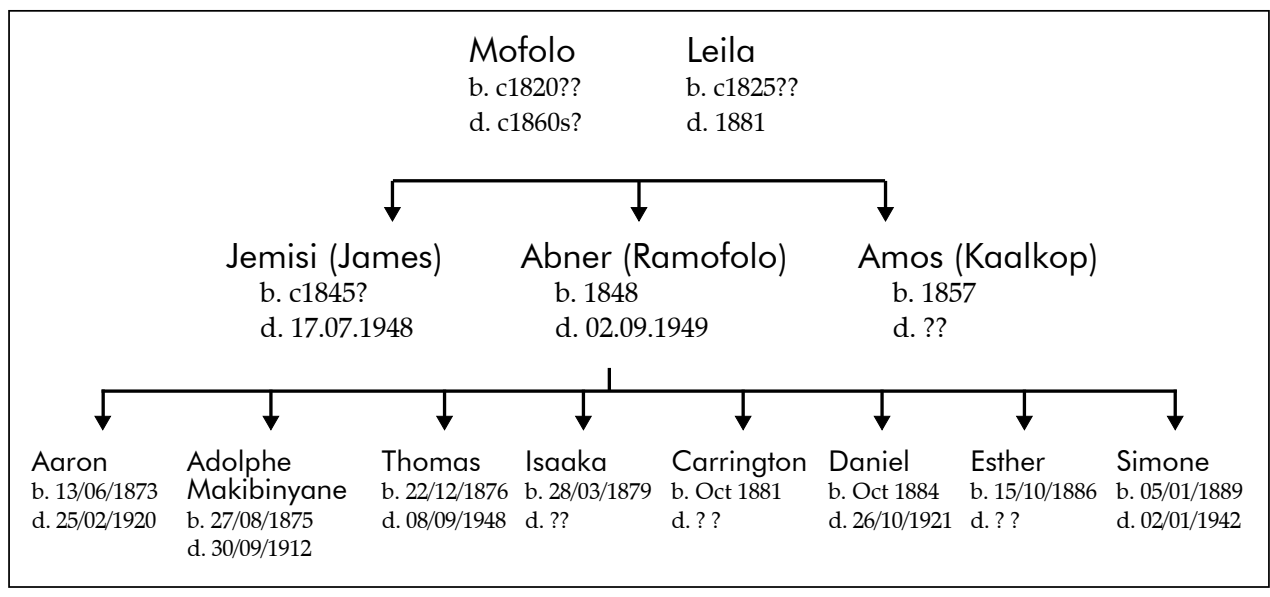

Figure 2: Mofolo family tree

\section{Move to Hermon: the growing influence of the church}

The church records show that Abner Mofolo's younger brother Amos (also called Kaalkop-"Baldy") was born at Hermon in 1857, so the family of Mofolo Sr and Leila had left Botheta and the hotly contested 'Caledon District' before the outbreak of the $1^{\text {st }}$ Basotho-Boer War in 1858 (Ntoa ea Senekal). Other members of the larger Mofolo clan may have remained behind in the Free State and the Cape.

The Mofolos were to remain in the Hermon area for over 20 years, and here they became more closely integrated into the life of the Protestant Church. ${ }^{2}$ The original parish records of Hermon for the period 1853-68 did not survive, and so fuller information about the Mofolo family during these years is not readily available. It may be possible, however, based upon parish reports and letters published in the Journal des Missions Évangéliques (JME), to give an overview of the growth of the parish, and how the Mofolo family may have fitted into these developments.

Rev. Hamilton Moore Dyke, after reconnoitring the area in late 1852, and meeting with Cochet at Hebron, began occupying the site for Hermon. By 1855, a school was established, a chapel was being constructed, and in 1856 the church had 36 full members, with 250-300 'listeners'.

It is fairly certain that the Mofolo family was a part of this growth in the church at Hermon. It is probably during this period that Jemisi (James) and possibly other sons of Mofolo Sr. became literate, and that Jemisi married Meitje (Miki) Chere. It is also likely that Mofolo Sr died during this period, but we know nothing of the circumstances of his death. ${ }^{3}$ The rapid expansion of the church continued during the following decade. 
This period also witnessed the intensification of the struggle for land between the Orange Free State and Lesotho, which culminated in the Seqiti War (1865-8). It is not clear how this war impacted upon the Mofolo family. Almost all of the PEMS missionaries were expelled from Lesotho by the Free State in early 1866, most of them taking refuge at Aliwal North. No doubt, the Mofolo family also fled during this period, and Abner and the other men would have joined in the defence of Lesotho against the invaders, but we have no details. Abner, a great storyteller according to his granddaughter 'Mapheko, used to regale them with tales of the Seqiti War in his old age, keeping his audience spellbound.

The result of the Seqiti War was that Moshoeshoe's kingdom was greatly reduced. The British Governor, Sir Philip Wodehouse of the Cape, and President Brand of the Orange Free State fixed Lesotho's boundaries as they are today. All land north and west of the Caledon river (Mohokare) was lost, as well as a significant portion of land to the east of the Caledon in the southern districts of Mafeteng and Mohale's Hoek. But Hermon was spared. Moshoeshoe died in 1870, a disappointed man, but also knowing that, if nothing else, Lesotho retained a modicum of separateness from its envious neighbour. The following year 'Basutoland' was given over by Britain to the Cape Colony for administrative purposes.

The security situation in Lesotho had begun to normalise by August 1869, and thus the former inhabitants of Hermon began to return to rebuild their villages and their lives. The school at Hermon re-opened in 1870, growing quickly from 72 pupils to 300 . From this point the church records are again helpful in highlighting important transitions in the Mofolo family which was settled at ha Khojane and nearby ha Raborikhuana.

In 1872, as I have already mentioned, Abner Mofolo married Aleta 'Mapheko, the daughter of Daniel Mputi and Mosili. The Mputi family had also entered Lesotho after spending many years in South Africa. Daniel himself was born at Graaff-Reinet, where his family had been refugees during the Lifaqane.

Abner is said to have been a short, dark man with a flattish face. He was very vigorous and hardworking, not bookish, but a very talented storyteller. ${ }^{4}$ His wife Aleta was tall, light in complexion, and rather strict. They were blessed with a number of children while resident at ha Khojane/ha Raborikhuana: Aaron (b. 13 June 1873), Adolphe Makibinyane (b. 27 August 1875), Thomas (b. 22 December 1876) and Isaaka (b. 28 March 1879). All were baptised and, by this point, the family was becoming better integrated into the Protestant Church. Carrington was born in 1881 while they were living at Mafeteng, and three others (Daniele, October 1884; Esther, 15 October 1886; and Simone, 5 January 1889) were born to them later at Qomoqomong during the 1880 s.

Hermon in the early 1870s was a thriving mission station under Emile Rolland and his father Samuel. Emile then joined the Government service in 1872 and became the first Magistrate at Mafeteng under the new administration of the Cape Colony. 
His departure led to the transfer of Dr. Eugène Casalis Jr to Hermon in 1872. Son of the founder missionary Eugène Casalis $\mathrm{Sr}$, he was a medical doctor, not an ordained missionary. This became a point of controversy within the congregation.

But there was a second factor leading to unhappiness: The forty year-old Protestant Mission in Lesotho was experimenting with a Synod which could make regulations in order to create a greater sense of unity and uniformity. Many of the Beersheba Christians living at Hermon, accustomed as they were to the traditions of Samuel Rolland, rebelled against the imposition of regulations. A storm broke out and D. F. Ellenberger from Masitise Mission was called to help restore order over the next three years, for which he earned the nickname Se-tima-mollo (The fire extinguisher). Ellenberger then handed over to Rev. Hermann Dieterlen, a newly-arrived missionary, the first with a university degree, and Hermon returned to being a hive of activity, one of the most prominent parishes in Lesotho.

After the Seqiti War, the church took significant steps to recognise formally the appointment of evangelists and teachers to oversee the work of parish outstations and schools, to introduce a representative Synod, and train evangelists and teachers, as well as establish a seminary for ordained Basotho ministers. There was a growing sense of self, an articulate class of leaders who started to express themselves more forcefully through church structures and through Leselinyana newspaper which was read across the sub-region.

\section{Prosperity, another upheaval and the move to Qomoqomong}

The 1870s were generally a time of growing prosperity after the deprivations and hardship of the Seqiti War (1865-8). Although Mofolo Sr had passed away, his wife and children seem to have done well. It is said that Mofolo Sr had been rich in cattle, and that his sons wore blankets (likobo tsa bolepo) and rode beautiful horses, quite the envy of those around them as they were some of the first to acquire such blankets. This anecdote, passed down through 'Mapheko, may provide some added insight into the sons of Mofolo Sr during the 1860s or 1870s.

Land pressures in Lesotho grew during this period, leading to the settlement of the larger mountainous regions of the country. Lesotho also experienced rapid social change and growing prosperity. Farmers, responding to new market opportunities at Kimberley where large numbers of diamond diggers congregated, exported over 100000 bags of grain annually. Thousands of Basotho men took short term contracts at the mine, or with railroad building projects or on White farms, and returned home with cattle, horses, guns, blankets and other valued items. However, all was not well. The seeds of a new conflict over authority structures were planted as Cape-appointed magistrates sought to hasten the pace of re-casting the Basotho in terms 'more acceptable' to European society. The senior sons of Moshoeshoe were unwilling to unite under the leadership of Paramount Chief Letsie, and popular 'protest' movements against the 
changing social conditions arose around matheke-theke. ${ }^{5}$ These were groups of women symbolically renouncing their ties to European manufactured goods, who disturbed what other observers thought was a time of great advancement.

This period of prosperity ended with new conflicts: the 'Moorosi Rebellion' in the Quthing District (1879) in the far south of Lesotho, and the Gun War (1880-1), which engulfed the whole country, and particularly Mafeteng District and adjacent areas, where the greatest fighting took place. This is where ha Khojane was located. Both conflicts were to influence the lives of the Mofolo clan. In the first conflict, Moorosi, chief of the Baphuthi, who had been incorporated in the far south of Lesotho as a long-standing ally of Moshoeshoe, refused to submit to the demands of the newlyappointed magistrate. Conflict ensued when the colonial regime felt he must be put down as an example to others who might disrespect authority. However, even with the help of Basotho, it took the colonial forces almost nine full months to subdue Moorosi. The defeat of the Baphuthi in Quthing District opened up the area for settlement to other Basotho, especially many of the 'Loyalists' from the Gun War as well as others who yearned for a better life.

The second conflict grew out of legislation which was passed at the Cape in 1878 to disarm all Africans so as to 'preserve the peace'; this law was then applied to Lesotho during 1880. By June, petitions to exempt the Basotho from the provisions of this legislation because of their proven loyalty to the Queen had been rejected by the Cape. Voluntary disarmament began in July, with Letsie, the Paramount Chief, Jonathan Molapo and a few other chiefs cooperating with the Cape authorities. Many others vehemently refused, led by Letsie's younger brother Masupha, and his most senior son Lerotholi. It did not take long for the Rebels to gain a large following, while the Loyalists became a small minority.

Abner Mofolo, according to his granddaughter 'Mapheko, was a Loyalist (Leteketa or Leteketoa, literally, those who received a 'ticket' in recognition of having handed over their weapons). The Mofolo men with their families were probably driven out of their villages by the Rebels or forced to flee for safety to the police camp and magistracy at Mafeteng in July 1880. It is not clear whether they were 'eaten up' as many Loyalists were, losing their animals and other property to those who opposed disarmament (the Rebels or 'Mabelete'), but this is likely, particularly because Khojane, their chief, aligned himself with the Rebels. A senior colonial official remarked that Khojane was a "rebel headman" and a "notorious rascal". ${ }^{6}$ Many Christians, from Hermon (and elsewhere), however, joined the Rebel cause, and thus the situation in the church was complicated.

At Mafeteng, the Mofolo clan would have worked alongside the Cape British forces during the coming months, helping to defend it against attack, the first of which took place in mid-September. Mafeteng was under siege by the Rebels, food was in short supply, and soldiers were placed on half-rations, until the camp was finally relieved a month later. Even if the Mofolos had wanted to remain at ha Khojane, they 
would have been very unsafe there or at Hermon, as the major British supply route to Mafeteng came in from Wepener and crossed between ha Khojane and Hermon Mission. Thus, it was a contested area and there were skirmishes and battles.

One of the first incidents of the Gun War took place at nearby Qalabane, where 31 Cape British soldiers were killed. Coming so early in the Rebellion, the Battle of Qalabane changed the course of the war, making the British Cape forces realise that much larger numbers of soldiers would be needed if they hoped to defeat the Rebels, thus greatly escalating the cost of the conflict, and raising serious doubts in Britain as to the wisdom of the methods being used in the disarmament campaign. Over the coming months, skirmishes were fought around the "camps", especially Leribe (Hlotse), Maseru and Mafeteng, with the greatest sustained action taking place in and around Mafeteng. Many villages within a $30 \mathrm{~km}$ radius of Mafeteng were burned by the Cape forces, and a series of running battles took place. By early 1881, attempts to call an armistice were already being made, and by June the war was over, though a new political dispensation took longer to work out.

What was the fate of the Mofolo clan? It seems no one was killed, but the conditions of war must have weighed heavily upon them, resurrecting memories of the Seqiti War, but worse. Loyalists generally found it difficult to return to their homes after the conflict ended, often being hounded by the victorious Rebels. Abner and his family surely suffered the same fate as they were still residing at Mafeteng camp, long after the fighting had ceased, together with more than 900 other Loyalists. This is where Abner and Aleta's son Carrington was born in October 1881, named after the famous Col. Fred Carrington, one of the commanders of the Cape Mounted Rifles at Mafeteng. It is likely that Abner's mother died at this time, and she may have been buried at Mafeteng town. ${ }^{7}$ The family of Abner then moved to Quthing a few months later in January $1882 .{ }^{8}$

Although not all Loyalists re-located after the war, the opening up of Quthing and the relationship with Ellenberger was probably very appealing, such that Abner and other members of the family joined the larger exodus and moved with hundreds of others from the Hermon/Mafeteng area to the south, many settling at Qomoqomong, about $15 \mathrm{~km}$ to the east of Masitise where Rev. Ellenberger served. Abner's younger brother Amos and family remained behind at Mafeteng until their daughter was born in July 1882, after which they too moved to Qomoqomong. Their elder brother Jemisi, however, had already chosen instead to move north to Cana in Berea District even before the Gun War where the church had requested him to serve as an evangelist. A few years later, he was appointed evangelist for Teyateyaneng, and thus it also became a centre for the Mofolo family in the years to come.

\section{Qomoqomong and Masitise}

The Mofolo family-like many others-were probably materially poorer for having sided with those who supported disarmament. Claims for compensation after the war 
were submitted, and efforts to regain stolen livestock were made, but it is not clear what was recovered or if any meaningful compensation was ever received. Now the families of Mofolo, 'Noto, Mohapi, Ngakana and others from Hermon would have to rebuild their herds and adapt to the new circumstances in the far south of Lesotho. Abner seems to have adapted well to life at Qomoqomong and prospered. He was an extremely vigorous, strong and resourceful man. His granddaughter 'Mapheko related that he developed a means of irrigating his fields by diverting water from the river, an uncommon practice at the time.

Qomoqomong is where Abner's children, including Thomas, began their formal schooling. It is probable that the boys only started schooling at the age of ten or twelve, first learning to herd animals and carry out other tasks central to the family economy. Z. D. Mangoaela (in Basutoland Witness 26-7) has written:

At that time this fertile valley of Qomoqomong, which attracted many settlers, afforded excellent pasture and grain lands. The hills and kloofs were still covered with natural forests and bamboo thickets; several streams flowed down the many gorges into the bigger stream Qomoqomong, on whose banks were rich fields of wheat, mealies and kaffir-corn. On the hills and plateau game abounded, groups of monkeys were still to be seen, and there were leopards which preyed upon the cattle of the people.

Thomas grew up among these beautiful natural surroundings, and the observant boy had a lot to learn from all these. With all the other Basuto boys he played, and herded his parents' cattle; and as he grew up, he sometimes went with the transport riders, leading the oxen which drew the waggons bringing in goods from the rail-head [at Aliwal North, about $90 \mathrm{~km}$ away to the west]; sometimes he joined the hunts organised for killing game or monkeys on the mountains; and he saw or heard of the killing of leopards at the cattle posts by the older men.

Thomas and his brothers were taught by the able and inspiring teacher-evangelist, Everitt Lechesa Segoete, who had himself arrived at Qomoqomong in late 1882 from Aliwal North. ${ }^{9}$ Segoete was a rare breed of person who, after undergoing training to become a teacher at Morija, lived a life of dissipation and recklessness in the southern Free State and north-eastern Cape. After converting in truth, he became a creative and forceful leader in the Protestant Church. His example of practical Christianity, marked by self-sacrifice and courage, made a deep and lasting impression on Thomas.

It was also here at Qomoqomong, that Thomas learned isiXhosa and English to add to Sesotho and Dutch, the languages used by his family. ${ }^{10} \mathrm{He}$ also learned more about cultural diversity because of the greater mix of ethnic groups in Quthing district and the neighbouring Herschel area. After finishing his lower standards at Qomoqomong, Thomas went to Masitise, $15 \mathrm{~km}$ to the west, where he finished his primary school education, probably in 1893 or 1894. Thomas was also confirmed as a full member of the local parish in 1894 . Because of the distance, he would have stayed 
with another family at Masitise or perhaps there were boarding arrangements. We are not certain if his brothers went on to higher primary at Masitise, but probably not.

Masitise was then the centre of a large network of smaller churches and schools, covering much of the western portion of Quthing District. Here Thomas would have come into contact with Rev. D. F. Ellenberger, then a veteran missionary and oral historian of over 30 years, having founded Masitise in 1866 after the Boer commandoes made his continued stay at Maphutseng (Bethesda) further to the north impossible during the Seqiti War.

\section{Schooling at Morija}

Thomas was an able student with a passion for learning and for the church. After completing his schooling at Masitise, he went on to Morija in 1894 to continue his education at the Bible School, ${ }^{11}$ a training ground for evangelists under Rev. Alfred Casalis. ${ }^{12}$ Founded in 1882 by Adolphe Mabille, the Bible School's "spiritual aim was to acquaint students as deeply as possible with the Bible and to imbue them with its spirit" (Couzens 280).

During these two years of study, Mofolo would have been exposed to "a general introduction to the Bible and the history of Israel, a brief survey of the Old Testament, and a study of the whole New Testament, the life of Jesus, the principal periods of ecclesiastical history and the fundamental doctrines of the Christian religion". In addition to Alfred Casalis, he would have been given instruction by Henriette Cochet, Nathan Sekhesa, Michael Mofokeng and others (Couzens 280).

Although Adolphe Mabille, the great leader of the second generation of missionaries, had passed away suddenly in May 1894, just as the new class of students was to begin their studies at the Bible School, Mofolo arrived in Morija during a decisive period in the history of the church in Lesotho. The Synod was to be re-introduced soon (and then in 1899 the Seboka as well) to give greater responsibility to the elders, evangelists, and ordained Basotho pastors in the decision-making of the church; and a Central Fund was being established to regularise the finances of the entire church.

Other Basotho evangelists and teachers were volunteering to go to far-away Barotseland (now western Zambia), in order to strengthen the mission there under Rev. François Coillard, a mission that had grown out of the pioneering exploratory and evangelistic work of Asser Sehahabane, an evangelist of major stature who had eventually returned to Lesotho after many years of devoted service in the northern parts of the Transvaal and Bechuanaland. The Mission to Barotseland was often described as a mission of Africans to Africans. From the 1860s, Mabille and others had believed the 'Church of Basutoland' would not mature fully unless it carried out its own mission work, and thus both Barotseland and the mountains of Lesotho received considerable exposure and emphasis. No doubt Mofolo and his classmates were regularly informed of developments in these mission fields, or read of them 
in the numerous articles that appeared in Leselinyana during those years; they must have seriously considered whether they too should volunteer to join in these pioneering initiatives.

After graduation in mid-1896, Thomas proceeded to the Normal School (Thabeng) where teachers were trained. Here the Principal was Rev. Robert Henry Dyke, a renowned educator who was ably assisted by a number of expatriate and Basotho staff, including Akim Sello and Michael Mofokeng. ${ }^{13}$ The enrolment during Thomas's time at the Bible School was 50, while 100 attended the Normal School.

Students came to Morija from many parts of Lesotho, the Free State, the Transvaal, Mozambique and Barotseland. Others, like D. D. T. Jabavu, were from prominent families in the Eastern Cape. These came to Morija not simply because it was a Protestant school with ties to their home churches, but also because its results surpassed even those of Lovedale and Healdtown, renowned missionary centres whose educational products would also wield great influence in the decades to come. Thus, Morija was a cosmopolitan centre, and Thomas would have learned a great deal through this exposure.

Morija soon became a small thriving town where the emerging Christianised elite began to develop organisational and broader business skills as well. Moving beyond teaching and church work, as well as government service (clerks, interpreters, and so on), this new generation dreamed of reviving agriculture, and entering into business and the various professions. For example, during the latter part of 1895, Basotho in different communities stretching from Port Elizabeth to Morija sought to develop what was called the 'South African Native Trading Association' which would help them to enter into and compete in business, then dominated by Whites (and in northern Lesotho by Indians as well). A depot would be opened in Port Elizabeth under the leadership of Frank Mokuena, one of the initiators of the association, and this would procure goods in bulk to be distributed to Lesotho (and possibly elsewhere along the route). This initiative included Abram Moshabesha, W. Posa, A. Sekhesa, P. Makume, N. Moshabesha and D. Kalaka, all prominent Morija residents. ${ }^{14}$ This association later tried to raise share capital from Basotho members as The Basuto Pioneer Trading Company. ${ }^{15}$ Although these efforts did not succeed ${ }^{16}$ they demonstrate the spirit of adventure and enterprise of this new generation, a spirit which no doubt impacted upon Thomas Mofolo as well.

This generation hoped to contribute to the development of Lesotho (and the broader region) in other ways as well. Some of their predecessors served as advisors and councillors to chiefs, while others aspired to see a new political dispensation where their talents and education could be put to greater use in the regeneration of society. It was believed that such aspirations would only be fulfilled if 'education and enlightenment' could be spread more widely, if chiefs as a class were more amenable to 'progress', and if the discriminatory attitudes and laws against black people could 
give way to more equality, especially in the Free State and Transvaal where black people were gradually being turned into servants on land from which they had previously made a living.

Part of this 'enlightenment' would come of course through writing and publishing. During the period from 1863, some like Filemon Rapetloane had submitted songs, poetry or stories to Leselinyana and helped Mabille with his translation of Pilgrim's Progress into Sesotho; others like Esaia Seele and Asser Sehahabane had written regular letters about their explorations and evangelisation in the Transvaal and Bonyai (Zimbabwe) respectively; while still others wrote about public affairs (Petrus Tsufu) or spiritual matters (Everitt Lechesa Segoete). Moreover, Nathaniel Makotoko had been quite instrumental in assisting Coillard with the translation of numerous hymns into Sesotho, and others assisted with the translation of portions of the Bible and religious material.

These men took pride in their writings and/or translations, but it was not until Azariel Sekese that any Mosotho published a book. Essentially a compilation of customary practices, proverbs and legends, Buka ea pokello ea mekhoa ea Basotho le maele le lits'omo had been serialised in Leselinyana during 1892 and 1893, and then published as a book. At the same time, Sekese published a series of articles on historical matters which appeared regularly in the newspaper. Sekese's rate of output set a new standard, and this would probably have stimulated other Basotho writers or aspirant writers to emulate his example.

Mofolo was thus studying during a period of ferment in which a new sense of consciousness was being born or manifested. This ferment can be seen in religious and spiritual matters as well. The Ethiopian Movement, for example, was beginning to gather momentum in parts of southern Africa. A number of Black church leaders, unhappy with the pace of change within mission churches, or the over-arching control of White missionaries, opted out and started their own churches from as early as 1882 .

Other Christians, such as Anna 'Mantsopa Makhetha, continued faithfully to carry out a range of practices including ceremonies with regard to drought, rain-making, hail, locusts, infertility and many other ailments using more traditional rituals and prescriptions. She was also a well-known prophetess who had been close to Moshoeshoe. In this way she upheld long-cherished systems of indigenous knowledge, while at the same time she was a reformer and a member of the church. She was castigated by some Christian leaders for her 'unorthodox' practices, but seems not to have been deterred. Her stance typified a growing recognition among Africans that missionaries had a limited understanding of the African worldview and way of life, such that Africans, though truly indebted in some regards to missionaries and Western civilisation, had to chart their own destiny, and not indiscriminately discard or undervalue their own larger heritage. ${ }^{17}$ 
Finally, let me mention the 'Holiness Movement'. Total consecration, the fullness of the Spirit, holiness-these are not new concepts in the history of the Christian Church, but from time to time new movements arise injecting new life into Christians. In 1889, Aline Mabille, a young unmarried woman of 25 years, brought together a group of women in Morija who wanted to live a life more fully consecrated to God. Through prayer, Bible study and a simple virtuous life, they tried to live in obedience to Jesus and be more like him, filled with his spirit. This small group roused some resentment among others in the community, who mockingly labelled them bahalaleli (the holy ones). Ten years later, the group had not only survived, but had grown in size, and eventually it became the Mothers' Union (Bo-'M'a-bana), the backbone of the church. It should be noted that Aline married Rev. R. H. Dyke, the principal of the Normal School in 1894, and must have come to know Thomas quite well over the coming years. ${ }^{18}$

While Mofolo was soaking in and learning from these and other diverse influences, his studies to become a teacher were almost interrupted because of his inability to pay school fees in 1897. This resulted from the Rinderpest epidemic which spread across southern Africa in 1896-7 and decimated the herds of cattle of almost everyone, both black and white. To make matters worse, a severe drought followed. No doubt this impacted badly upon the Mofolo family at Qomoqomong as well, and Thomas was forced to resort to other strategies to generate income. During vacations, according to his daughter 'Mapheko, he is said to have walked to 'Gauteng', the place of gold to make bricks and do other manual labour which would earn much-needed money to pay his school fees. ${ }^{19}$

'Mapheko goes so far as to assert that Thomas's father Abner did not put a lot of stock in this type of bookish education and that he was not very willing to help Thomas in this regard, even though he had the means to do so. This possibility is substantiated by Rev. Alfred Casalis, who wrote as follows:

[Rev. D. F. Ellenberger] eventually defeated the resistance of [Thomas's] father who authorised the boy to go to Morija [in 1894] and continue his studies, but on the condition that he [the father] not be expected to reimburse anything for his [Thomas's] education. Finally, the father abandoned his son to the missionaries.

It should be understood that his father did not pay a cent for him, and even showed complete disinterest in him; the poor boy often had to stay at school during holidays, or had to be invited by his classmates, as his parents did not want to see him and refused to send a horse to fetch him at the end of term. (qtd. in Brutsch 37)

It is probably for this reason that Casalis erroneously thought Mofolo's parents were "entirely pagan and in a general way opposed to Christianity". The perception that Abner was unwilling to help, however, may be an over-simplification, whereas the situation was more complex. It could be that as a farmer and rancher, Abner placed 
more emphasis on hard work and other traditional pursuits. Casalis did not seem to comprehend that Abner and his family were Christian, but Abner-for his part-may not have been in a position to fully assess the merits of Thomas's desire for a higher education at Morija. It is not certain what Thomas' mother felt about these matters. Thomas, however, clearly excelled at academics and pushed hard to receive further education despite the obstacles which he had faced. While Thomas maintained a firm interest and understanding of more practical pursuits, his destiny seemed to lay elsewhere. Mofolo explained many years later to the literary scholar G. H. Franz (qtd. in Kunene 22):

On account of the Rinderpest I lacked money for school fees, and [I] wrote and told Rev. Dyke that I was not coming back to school in 1898. During that week I went to the Maloti to bring down horses to take me to work amongst the white people [in South Africa]. At dawn I set out to go to work, but when I passed the post office I found a letter from Mr Dyke which prevented me from going and ordered me back to school permitting me to complete my studies "on credit". I turned back at once and went home to tell my parents of the change of plans. In 1898 I passed my third [and final] year [at the Normal School]...

The fact that Thomas's school fees had been paid up until that point means that his family had been supporting him; until, that is, they lost so much of their store of wealth through the Rinderpest. Moreover, after receiving the good news from Rev. Dyke, Thomas decided to go home to share this good news with his parents. Clearly, Rev. Casalis was not fully informed of the situation, and seems to have misjudged the motives and character of Thomas's father. It may be that Abner did not give enough value to the higher studies of Thomas, but to claim, as Casalis did, that he was completely uninterested was a gross exaggeration.

By the time Thomas finished his studies in 1898, and earned his Teaching Certificate, he was 22 years old. By persevering and completing his studies successfully, Thomas placed himself within a growing and forceful group of educated Basotho who, despite their relatively small numbers, would play an increasingly important role in the future, not just in the church, but within the broader society as well. Some of his classmates included people like Jeriel Pheko, who went to Barotseland as an evangelist, Edward Thabane, who became a well-known evangelist in the Sehonghong-Thaba-Tseka area, and Azariele Moerane, a strong character from Masite near Morija who emigrated soon after completing his training to become a teacher in East Griqualand at Paballong under Chief Lebenya. He fathered many remarkable children, including Epainette, a daughter, who became the mother of Thabo Mbeki, the South African President (1997-2008). I mention these few examples because Morija attracted many extremely able students who became leaders of great stature in their various communities. 
These Basotho leaders, together with their counterparts across the border, increasingly interrogated not only the legacy of their own societies, with its strengths and weaknesses, but also that of the missionaries and colonial officials in Lesotho, and the white settlers in South Africa. ${ }^{20}$

\section{Teaching and other pursuits}

Rev. Alfred Casalis took Mofolo in after his graduation from the Normal School. Having taught Mofolo at the Bible School, he had followed his progress through the Training College, and saw in him a bright prospect. Thomas was employed to work at the Morija Sesuto Book Depot, the centre of publishing in Lesotho, and a place where other opportunities could easily arise for a bright young man.

Thomas worked there until the latter part of 1899. Because the Anglo-Boer War had just broken out, paper and other materials were in short supply, forcing the partial closure of the Book Depot and Printing Works. ${ }^{21}$ Thomas was then encouraged to go to Leloaleng, the Industrial School near Masitise, where he learned carpentry and assisted with teaching during 1900 and 1901. Casalis (134) said of him that "it did not take long to prove that he was just as clever with his hands as he was with matters of the intellect". Mofolo then proceeded during 1902 to teach at Bensonvale, a Methodist school across the border at Sterkspruit near Herschel, which was then a vibrant centre of activity.22 But Mofolo's stint there may have only lasted for six months or so.

At that point, Rev. R. H. Dyke, Thomas's Principal at the Normal School, recalled him to Lesotho and arranged a teaching post at the Protestant School at Maseru. Maseru was then a small colonial outpost, the centre of British administration in Basutoland. Small as it was, with only about 1200 inhabitants, it was nonetheless a place of growing activity, with the newly-established National Council opening there in 1903. This body, composed of 95 chiefs and headmen, and five appointees from the educated elite, was to become the main official forum for advising the colonial administration in Basutoland.

The chiefs, after valiantly rallying the nation during the Gun War two decades before, had lost some of their standing in the nation through constant clashes between themselves, disputes over territory, alcohol abuse, arbitrary decisions and the imposition of heavy fines upon those who lost court cases, fines which helped to prop up the livelihoods of the same chiefs. As such, the overwhelming representation of the chiefly class in the National Council seemed unjustified to some. The very limited representation of the educated elite was a reality which galled them, as they believed their attainments should have resulted in a larger public voice and role for themselves. It is not surprising, therefore, that the bahlalefi (the enlightened ones) soon thereafter started to establish their own independently-run newspapers and political organisations so as to broadcast more forcefully their views on many matters of national import. 
Across the border, the period following the Anglo-Boer War ushered in greater hope as well among educated Africans. It was believed that the more liberal franchise in the Cape which allowed educated and propertied Africans to vote might be extended to Natal, the Orange Free State and Transvaal, such that when the proposed union of these four territories was realised, black people might be better off. Though these hopes were to be very badly disappointed, they stimulated new ideas about where African leaders wanted to move the larger society which was being transformed by the new wealth accruing from mining and other economic developments in the region, as well as the growing inequalities which were being exacerbated by legislation, underpinned by a distorted form of Christianity practised by the majority of white Christians, who wanted to become, it seemed, a permanent elite, superior to black people and other racial groups.

But while the region was being transformed economically, natural calamities were once again transforming some people's lives negatively. It was in May 1903 that Thomas's father Abner left Qomoqomong and went to Bethlehem. His fortunes, first disrupted by the Rinderpest, seem to have been dealt another blow by the extraordinary fall of snow in southern Lesotho during June 1902, which killed thousands of cattle and sheep. Abner Mofolo left for the Orange Free State, probably to join one of his elder sons there.

Meanwhile, Thomas Mofolo taught at Maseru until being recalled to Morija in April 1904 by Rev Alfred Casalis (142) ${ }^{23}$ who wrote: "[Thomas had now] undertake[n] the necessary studies to become a useful member of the Mission. With his teaching diploma, his written and spoken fluency in English, his impeccable written and spoken Sesotho, rich in idioms and vocabulary, and having read and observed widely, he was now ready and he offered me his services". Casalis paid Mofolo the salary of a qualified teacher. According to Casalis (142), "Mofolo quickly became the best collaborator in the extension of our work, both intellectual and religious, through books and newspapers".

\section{Thomas's marriage to Francina, and the Morija Sesuto Book Depot}

By the time Mofolo left Maseru to rejoin Alfred Casalis, his life was already taking on a new dimension, for while teaching there, he had met a young woman who captured his imagination. The young woman was Francina Mats'eliso Shoarane, whose family stayed at ha Abia near Masianokeng, just south of Maseru. While busily sinking his roots into his new employment at Morija, Thomas made plans to marry Francina, and the marriage took place on 15 November 1904 at Masianokeng. It was conducted by Rev. Baltzer, the parish minister at Thaba-Bosiu, Masianokeng being an outstation of Thaba-Bosiu. Francina's father Monts'o, a policeman, was present. ${ }^{24}$ It is not clear who represented Thomas from his family at the wedding, but it may well have been his father's elder brother James, perhaps the most senior person in close proximity as he had long been resident at Teyateyaneng, about $40 \mathrm{~km}$ to the north of Masianokeng. 
We know very little, unfortunately, about Francina, but there are a few points we can note. The first that we notice her is in February 1903 when her short letter is published in Leselinyana, not a common matter by any means for a woman, especially from someone who was no more than 18 years of age at the time. Men filled the newspaper with their writings, but not women, not even missionary women, though the 'grandmother of the Mission', Adele Mabille, did write from time to time. Thus Francina was a cut above average to be sure, and this may be what had sparked Thomas's interest in her.

Alfred Casalis adds significantly to this picture. He recorded the following short passage in his Souvenirs which he put together after returning to France in 1906. The passage provides us with an interesting and tantalising glimpse into this rather remarkable young woman:

I had enlarged and refurbished a house ${ }^{25}$ for him [Mofolo], situated in close proximity to ours; he had taken for himself a young Xhosa woman, ${ }^{26}$ very intelligent, who had received a very polished education from an excellent institution in the Cape Colony. Mofolo had made the furniture himself and had arranged their home according to his taste, and to that of his wife. She spoke and wrote fluently her mother tongue of Xhosa, as well as Sesotho, English, and a little South African Dutch, the "Taal", like her husband. She was also a very good seamstress and cook, talented in all of the feminine duties of marriage and the organisation of the home. (qtd. in Brutsch 43)

This brief portrait of Francina is then amplified by Casalis:

One evening, when I went to speak with Mofolo about an urgent matter which I wanted to confide in him, I found the newly-married couple seated in the room which Mofolo had arranged as a sitting cum dining room. They had illuminated the lamp after their meal; the young woman was sewing while her husband was reading to her from a book on astronomy which I had given to him, a popular work written in English. It was a very new spectacle, and also unexpected in a village of Basotho; it was also a proof of the perseverance and hard work which the missionary wives have done towards raising the intellectual level of indigenous women in order to be companions and not slaves of their husbands... (qtd. in Brutsch 44)

It seems from these brief passages that Thomas had found a woman of high calibre, one who met his expectations for a wife and partner, much as he would later describe Aria Sebaka in his book on courtship, Pitseng. Nonetheless, little more is known about Francina, and thus, as is so often the case, women disappear from the narrative, and there is precious little one can do to resurrect their voices and allow them to be heard.

Thomas's life and his doings, in contrast, are much better known. Over the next few years, his life was to be extremely productive in a professional sense. He worked at the Morija Sesuto Book Depot as a proof-reader, secretary for 'native correspondence', clerk and general assistant to the Manager, taught at the Bible School, and later worked as a 
part-time reporter for Leselinyana. Rev. Casalis was his boss and perhaps his mentor as well, one who had great admiration for Thomas's amiability, hard work and intelligence.

The cordial relationship which Thomas enjoyed with his employer seems to have continued when, at the beginning of 1906, there was a handover of responsibilities. Casalis returned to France and was replaced by Sam Duby. ${ }^{27}$ It was during this period at the Book Depot under Casalis and Duby that Mofolo read as widely as he could and developed an interest in writing literature.

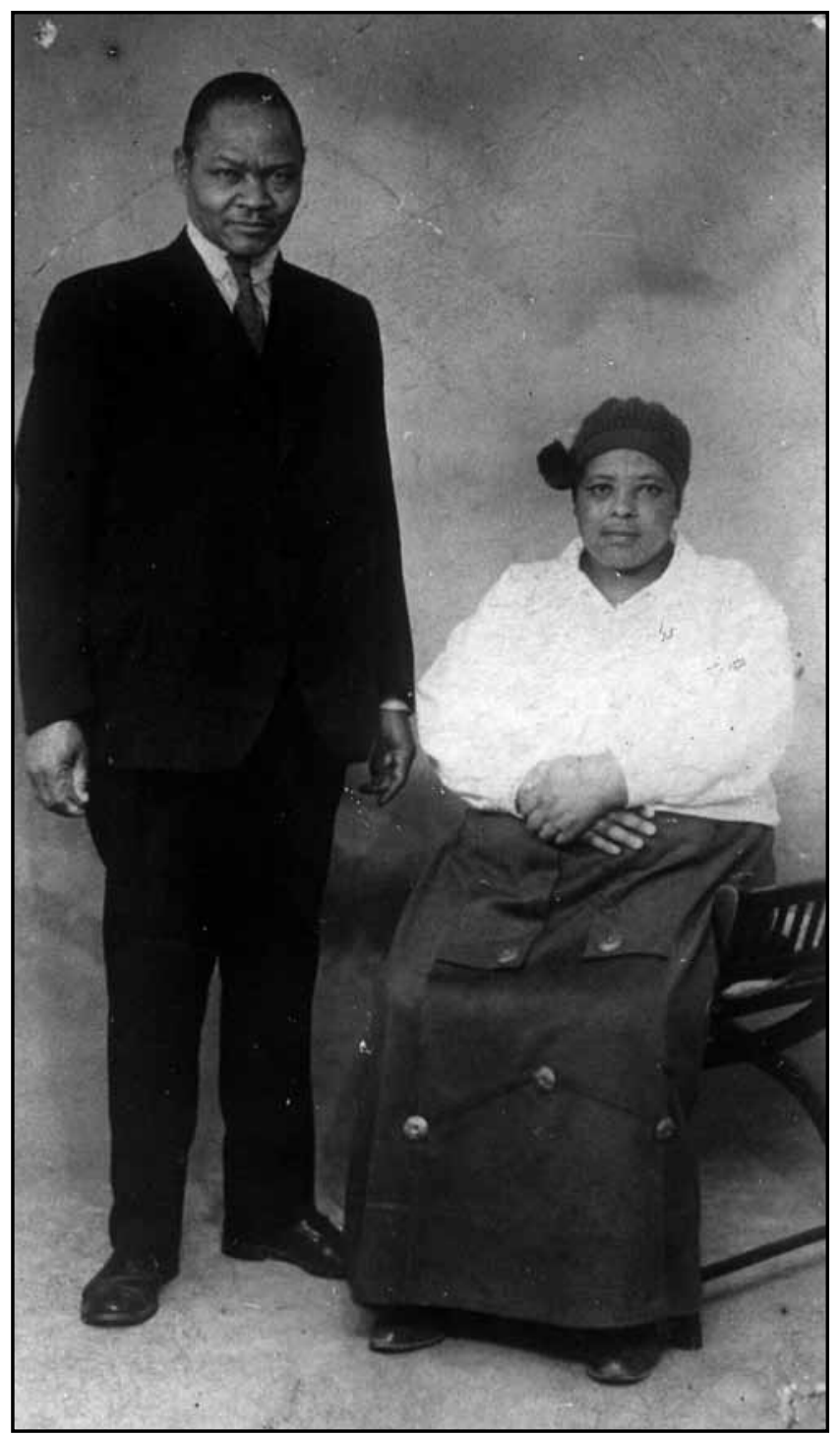

Thomas Mofolo and his third wife Emma in 1936 (East London). Used by permission of 'Mapheko 'Mamofolo Mofolo 


\section{Conclusion}

In this initial submission on the life of Thomas Mofolo and the contexts in which he and his family lived, as well as their antecedents, I have tried to gather together fuller information through archival work and oral interviews that may be of interest to researchers and other readers. The story ends in 1905-6, just at the point when Mofolo's literary career begins. It is perhaps too early to evaluate the significance of this emerging picture, or whether it will change the way Mofolo's literary works are interpreted. Considerably more research remains to be carried out in order to add more texture to the story and refine the analysis.

During the four to five years after this biographical sketch ends, Thomas Mofolo wrote his four literary works (of which three were eventually published) while living and working at Morija. This groundbreaking work did not emerge out of a vacuum. As we have seen, Mofolo was part of a generation which was poised and ready to play a greater role in a number of fields, and he was personally living in a supportive and engaging environment within the context of the mission at Morija. Nevertheless, the quality of his work, and in particular his last novel Chaka, seems in some respects to have risen far above the foundation he had received.

For even now, a century later, Chaka still attracts fresh attention from literary scholars and others who would like more fully to plumb the depths of Mofolo's individual genius. In this short biographical sketch, I have attempted to paint a fuller picture of Thomas Mofolo's family, its antecedents, and the various factors which might have influenced him in his upbringing in a number of different contexts. Further research which I have undertaken has uncovered additional information concerning his life after 1905. This new information about his life, both before, during and after his literary productions, may be of some value to literary scholars, anthropologists, historians and other researchers. This fuller account will be published at a later date.

What seems most poignant at this point, however, is a sense of inadequacy. However much we may come to understand about Mofolo's biography or his family and its circumstances, one feels as if his heart and soul are still clothed to an extent in secrecy. These are obviously revealed in his literary works, but one would desire to know much more. Without the earlier drafts of Mofolo's manuscripts, or his personal journals and correspondence, or his personal reflections on the creative process, one still feels rather distant from this remarkably creative person who, within the space of a few frenetic years, set such a high standard for Sesotho and African literature. It is incumbent upon us, therefore, to seek additional material, both archival and oral, which might shed greater light on Thomas Mofolo, and to carry out studies which creatively interpret his literary works in such a way that these might also shed light upon their author and his evolution as a person and a writer. 


\section{Acknowledgements: Motho ke motho ka batho}

Every researcher is indebted to those far-sighted individuals and organisations who have collected, preserved, and properly organised records from the past in archival collections; other researchers and writers who have laid a foundation upon which to build; and living informants who share of their personal knowledge and oral traditions, without which our research would be much the poorer. I would like to single out a few key people and institutions in this regard:

Prof. Daniel Kunene, whose study of Thomas Mofolo and his novels, and translations into English of these novels, is by far the greatest contribution to date concerning Mofolo and his legacy.

Rev. Albert Brutsch, one of my key mentors at Morija Museum and Archives during the period 1989-99, and a man whose contribution over five decades to the building up of the work and collections of the Morija Archives can hardly be overstated. His notes on Thomas Mofolo, compiled during the late 1970s and 1980s to assist Daniel Kunene and other researchers, were a mine of useful information

'Mapheko Mofolo-Chesi, who introduced me to her rakhali, 'Mapheko 'Mamofolo Mofolo, the only surviving child of Thomas Mofolo (by his third wife, Emma). Rakhali 'Mapheko was born in 1933, and has been a very engaging and helpful informant, one who has greatly enriched this research with her knowledge of the Mofolo family, and her anecdotes which add such important colour and texture to this story that it would have been much the poorer without her. Through her I have met many other members of the extended family.

Leila and Brigitte Hall, for assistance with the translation of certain French materials.

Thabo Maketekete Sekonyela for freely and enthusiastically sharing his research on the Bataung ba Molete.

My appreciation also goes to Dr Madalina Florescu for numerous stimulating conversations concerning Mofolo and the inter-cultural engagement between missionaries and Basotho, conversations carried out while she was resident at Morija during July-August 2015 under the auspices of the French Institute.

Finally, my thanks to Ms Petty Tizora, a cartographer at the Unit for Geoinformation \& Mapping, University of Pretoria, for drawing the map accompanying this article.

\section{Notes}

1. See Beersheba/Hermon Register: "Abner Mofolo, mora oa Mofu Mofolo le oa Leila, motlankana a tlagileng Botheta, o nyala Allita, morali oa Daniel Mputi le oa Mosili, moroetsana a tlahileng K'eme" (138). This is labelled No.17. The marriage at Hermon was carried out by Rev. Adolphe Mabille.

2. Hermon Mission had originally been planned for the west side of the Caledon (Mohokare) river in the late 1840s. However, because of various uncertainties, the actual founding took place on the east side of the river in 1853 under Rev. Hamilton Moore Dyke. Dyke was brother-in-law to Eugène Casalis, who was one of the first three missionaries to Lesotho. Hermon fell squarely within Moshoeshoe's territory, and thus, the Mofolo family — by settling at nearby ha Khojane in the 1850s—became part and parcel of Moshoeshoe's kingdom as well.

3. Mofolo Sr. was probably between 45 and 55 years of age during the mid-to-late 1860 s. It is possible that he was killed during the Seqiti War.

4. I am much indebted to the stories, traditions and personal experience of 'Mapheko Mofolo, born in 1933, and one of two surviving grandchildren of Abner. It is she who supplied this description of Abner, also called Ra-Aaron after his first-born son. 'Mapheko knew Abner personally. She was the last child of Abner's son Thomas Mofolo by his third wife.

5. A nervous 'condition' characterised by staggering or hysteria. Missionaries characterised these women negatively as suffering from a form of 'group hysteria', which was quite extraordinary in its 'disruptive consequences', but the phenomenon may require deeper analysis. Is it possible that these women were actually undergoing a spiritual experience of an ecstatic nature, a trance experience that was by no means uncommon in the region?

6. See letter of Arthur Barkly (Magistrate of Mafeteng) to his father Sir Henry Barkly (former Governor of the Cape Colony) of 14 August 1880 (in Fanny Barkly 150-2).

7. Leila may only have been between 55 and 60 years old at the time. It is not clear what the cause of death might have been.

8. Because the Mofolo brothers were Loyalists, none seems to have stayed on at ha Khojane after the Gun War, and thus the site of their residence from the 1850s till 1880 eventually became no more than a memory.

9. The unpublished Souvenirs manuscript of Rev. Alfred Casalis, which Rev. Brutsch made notes from, is 
an important source of new information about Mofolo, though some of Casalis' observations must be taken with care. According to Alfred Casalis, Thomas attended an afternoon/evening class specifically created to instruct shepherds, not the normal day school attended by other children. Casalis claims that even this concession had to be wrested from Thomas's parents who had put up resistance (qtd. in Brutsch 381). Attending the school, which was a considerable distance from their home, may have presented certain logistical challenges. Certainly, many others faced similar challenges, and overcame these. Thomas apparently did as well.

10. I believe that Thomas' mother Aleta was a Mophuthi. ('Mapheko also thinks the same.) Her mother tongue may well have been Sephuthi, a dialect close to Siswati which had been further "Sotho-fied" by long association with Sotho-speaking peoples. If Aleta spoke Sephuthi to her children, it would have made it much easier for them to acquire another Nguni language as well, like isiXhosa, especially in an environment like Qomoqomong with such ethnic diversity all around them. Whatever the case may be, the Mofolos found Qomoqomong a congenial home, and descendants of the Mofolo family, especially Amos's branch, can still be found there and at other villages in Quthing District up until today.

11. Alfred Casalis stated that Mofolo started at the Morija village primary school, and only afterwards did he go to the Bible School (qtd. in Brutsch 115-6). The Bible School Register shows that he arrived there in 1894, but gives no date. Thus, it may be that Mofolo spent a session at primary school for a bit of "bridging" during which time he boarded at the Casalis house, after which he transferred to the Bible School and its boarding facilities.

12. Son of the pioneer missionary Eugène Casalis, but by his second wife, Alfred was born and raised in France, and only came out to Lesotho in 1889 where he was tasked with the establishment of Qalo Mission. Upon the death of Adolphe Mabille in May 1894, he was summoned to Morija to take over the work of the Bible School, as well as the Sesuto Book Depot, Leselinyana and the Printing Works.

13. R. H. Dyke was the son of Hamilton Moore Dyke, who had been the missionary at Hermon during the 1850s and 1860s when Thomas's mother had become a believer.

14. Abram Moshabesha also wanted to open a school for stone masons and other trades related to building. See "Tsebiso", Leselinyana 15 Hlakubele 1895, p. 2.

15. See in particular Leselinyana 1 Phupu 1895 (p. 4), 1 Pulungoana 1895 (p. 4), 1 Hlakola 1896 (p. 4 ), 15 Hlakola, 1896 (p. 4), 1 Phato 1896, (p. 4), and 1 Mphalane 1896 (p. 4).

16. It may be that this initiative failed largely because of the Rinderpest, which decimated the store of capital which formed the basis for many who would have otherwise invested in the Basuto Pioneer Trading Company. See "Mehla e mebe", in Leselinyana, 1 Phupu 1897, p. 4.

17. This self-confidence and ability to evaluate one's own society as well as that of others was in some respects not new at all. Moshoeshoe and many others often exemplified this ability. What was perhaps different now was the fact that it was the multi-lingual, multi-cultural, educated Christian elite who shared these views, some of whom possessed the intellectual tools to move the debate to new levels. See for example Z. D. Mangoaela in his book Tsoelo-pele ea Lesotho (1911), in which he stated that the task for Africans was to discern the best of both worlds and seek a creative synthesis of them.

18. Rev. Dyke's first wife passed away in 1894, leaving him with six children to raise, after which he married Aline Mabille, his cousin.

19. Gauteng, the place of gold, is a very old name among Basotho, and was used by Mofolo's daughter 'Mapheko. Leselinyana, the newspaper in the mid-1890s frequently used the term, then spelled 'Gaudeng' for Johannesburg.

20. A good example of the growing sense of self and nationalistic fervour among educated Christians can be found in the articles of Jos. M. Mofolo, perhaps the eldest son of James born in 1871. Three articles of his appeared in Leselinyana during 1896, and they exude a spirit of bravery reminiscent of the previous generation which had fought so hard to defend Lesotho against the Orange Free State. See: "Boloka se-Haeno" (1/5/1896 p.3); and "Mokhosi oa Khuebo" (15/12/96 p. 3) and "Khotso ebatang" (same issue pp. 3-4).

21. See for example the notice (Tsebiso) of Rev. Alfred Casalis in Leselinyana, 15 October 1899, p. 4, alerting customers in South Africa not to place orders or send funds because roads are being closed and normal business relations are being disrupted.

22. This centre of learning at Herschel was established in 1876 on a small basis, but was considerably enlarged and transformed in 1898. Here, Mofolo would have become much more aware of the larger political and cultural currents among educated African Christians as the Eastern Cape was the centre of the birth of a new consciousness among them from the 1870s. By the 1880s, a few Basotho like Simon Majakathata 
Phamotse and Josias Semouse were attending the leading schools such as Lovedale and returning to Lesotho with a broader understanding of the struggle ahead. See for example Andre Odendaal (33ff).

23. Casalis had been on leave in Europe from late 1901 to early 1904. Upon his return, he called Mofolo back to the Book Depot.

24. Monts'o Shoarane was a long-serving member of the Police in Basutoland, and went on to serve in north-eastern Bechuanaland. During the period from 1888 to the 1920s, hundreds of Basotho police served in Bechuanaland. Some, like Monts'o, settled there and did not come back to Basutoland. Interview with 'Mampolokeng Shoarane at ha Abia, 23 June 2015.

25. The house that Mofolo and his wife stayed in may well be the one which still stands, immediately behind the old Sesuto Book Depot building and within 50 metres of the Principal's House where Casalis lived. These now form part of the grounds of the Morija Girls School, which took over the property of the Bible School in the early 1950s.

26. Casalis is incorrect here. Francina spoke isiXhosa because of her schooling in the Eastern Cape, but the Shoarane family are actually Basotho of the Bakubung clan, closely related to the Bataung. Interview with 'Mampolokeng Shoarane, ha Abia, 23 June 2015.

27. A careful reading of the letters and/or journals of R. H. Dyke and Sam Duby (or others associated at that time with Mofolo) might well reveal more about the life of Thomas and Francina Mofolo.

\section{Works Cited}

Archival materials at Morija Archives

Basutoland Witness. April-June 1951. Journal.

Bible School Register. 1882-1975. Morija.

British and Cape Blue Books, 1879-85.

Brutsch, Albert. Thomas Mofolo Exercise Book. Notes of his own research, including excerpts from Alfred Casalis Souvenirs. Unpublished, n.d.

Church registers (baptismal, marriage, membership, kabelo, etc.). Morija.

Consistory Minutes for the Parishes of Beersheba, Hebron, Hermon, Masitise, Morija, Thaba-Bosiu and Cana.

Historical maps of Lesotho, Free State and Transvaal.

Journal des Missions Évangéliques. 1847-70. Journal.

Leselinyana. 1863-1905. Newspaper.

Minutes of the Missionary Conference, 1848-1906. Morija.

Minutes of Synods, 1894-1904. Morija.

The Basutoland Evangelist Aid Fund / Gospel Work in Basutoland. late 1888-1909.

Other Sources

Barkly, Fanny. Among Boers and Basutos. Westminster: Roxburghe Press, 1898.

Casalis, André. Alfred Casalis: Aventures Africaines. Saint-Estève, 2009.

Christol, Frédéric. L'art dans l'Afrique australe, Paris: Berger-Levrault, 1911.

Couzens, Tim. Murder at Morija. Johannesburg: Random House, 2003.

Ellenberger, D. F. \& J. C. MacGregor. History of the Basuto: Ancient \& Modern. Morija: Morija Museum \& Archives, 1992 [1912]. Facsimile reprint.

Kunene, Daniel P. Thomas Mofolo and the Emergence of Written Sesotho Prose. Johannesburg: Ravan Press, 1989. Litaba tsa Lilemo. Morija: Sesuto Book Depot, 1932.

Odendaal, Andre. The Founders: The Origins of the ANC and the Struggle for Democracy in South Africa. Auckland Park: Jacana, 2012.

Sander Peter. Throwing Down White Man: Cape Rule and Misrule in Colonial Lesotho, 1871-1884. Morija: Morija Museum \& Archives, 2010 